$\S=-1$

\title{
The Evaluation of Dissolved Oxygen (DO), Total Suspended Solids (TSS) and Suspended Sediment Concentration (SSC) in Terengganu River, Malaysia
}

\author{
Noorjima Abd Wahab ${ }^{1}$, Mohd Khairul Amri Kamarudin ${ }^{1,2}$, Mohd Ekhwan Toriman ${ }^{3}$, Frankie Marcus Ata ${ }^{1}$, \\ Hafizan Juahir ${ }^{1}$, Adiana Ghazali ${ }^{1}$, Atikah Anuar ${ }^{1}$ \\ ${ }^{1}$ East Coast Environmental Research Institute (ESERI), Universiti Sultan Zainal Abidin, Gong Badak Campus, 21300 Kuala Nerus, \\ Terengganu, Malaysia \\ ${ }^{2}$ Faculty of Applied Social Science, Universiti Sultan Zainal Abidin, Gong Badak Campus, 21300 Kuala Nerus, Terengganu, Malaysia \\ ${ }^{3}$ Faculty of Social Sciences and Humanities, Universiti Kebangsaan Malaysia, 43600 Bangi, Selangor, Malaysia \\ *Corresponding author E-mail: mkhairulamri@unisza.edu.my
}

\begin{abstract}
Terengganu River Basin is situated in the north eastern coastal region of Peninsular Malaysia. 29 sampling stations were selected. The water quality parameters were measured such as Dissolved Oxygen (DO), Total Suspended Solids (TSS) and Suspended Sediment Concentration (SSC). Results showed that the range of DO $(2.11 \mathrm{mg} / \mathrm{L}-8.07 \mathrm{mg} / \mathrm{L})$, TSS $(0.4 \mathrm{mg} / \mathrm{L}-128.2 \mathrm{mg} / \mathrm{L})$ and SSC $(0.07 \mathrm{mg} / \mathrm{L}-$ $25.6 \mathrm{mg} / \mathrm{L}$ ). The distribution of land use and land cover activities effected to the level of water quality in watersheds. The analyses of variance (ANOVA) was applied and provide a better understanding for the complex relationships among water quality parameters. Graphical data helps a better view of the overall analysis to appoint sources of pollutants to their effect. Terengganu River Basin is a shallow and has a sensitive ecosystem that responds to the land use changes and development activities of its surroundings. Water quality analysis showed that TSS and SSC were higher in the dry season but DO were higher in the wet season. Overall, the water in the Terengganu River Basin classified slightly contaminated especially the main sources of pollutants were possibly waste products and waste from development activities such as sand mining, farming, residential and agricultural.
\end{abstract}

Keywords: Terengganu River Basin; Water Quality; Dissolve Oxygen (DO); Total Suspended Solid (TSS); Suspended Sediment Concentration (SSC).

\section{Introduction}

A river is a natural flowing towards an ocean, sea, lake or another river. The river flows into the ground and becomes dry at the end of its course without reaching another body of water. Water plays an essential role in human life and environmental. Water is often used for domestic purposes especially for drinking. Water for different purposes has its own requirements for the composition and purity and each body of water has to be analyzed on a regular basis to confirm the suitability and sustainability. Water is the most important for sustaining life and resource in all economic activities associated with agriculture, industry and urbanization. Water pollution is a phenomenon that is characterized by the deterioration of its quality as a result of various human activities, land use distribution and climate changes [1-4]. The type of water contamination is directly related to anthropogenic practices and non-point or point source, which can be quantified in terms of the population density and land use type in the watershed [21, 22]. The study includes three methods that were used in this research including Dissolved Oxygen (DO), Total Suspended Solid (TSS) and Sediment Suspended Concentration (SSC). Therefore, the objectives were to determine and classify Water Quality Index (WQI) based on connection between TSS, SSC and DO at the monitoring stations along the Terengganu River Basin. DO is a measure of the amount of oxygen freely available in water and it is commonly expressed as a concentration in terms of $\mathrm{mg} / \mathrm{L}$. DO refer to the level of free, non-compound oxygen present in water or other liquids. It is an important parameter in assessing water quality because its influence on the organisms living within a body of water. TSS are solids in water that can be trapped by a filter. It is both a significant part of physical and aesthetic degradation and a good indicator of other pollutants, particularly nutrients and metals that are carried on the surfaces of sediment in suspension. TSS can include a wide variety of material, such as silt, decaying plant and animal matter, industrial wastes, and sewage. High concentrations of suspended solids can cause many problems for stream health and aquatic life. SSC is generally transported within and at the same velocity as the surrounding fluid (water or wind). SSC data are produced by measuring the dry weight of all the sediment from a known volume of a watersediment mixture. The problem of this research is address the issue of the validation of relationship between the quantitatively the water quality in rivers and physical-ecological interactions between the ecological variables. This study to develop a simple estimation tool for outlining oxygen demand parameter of concern in the Terengganu River which are to determine the concentration levels of DO level on the oxygen budget from oxygen demand parameters, TSS and SSC concentration level. Secondly to utilize a correlation and simple linear regression equation model to estimate the extent of depletion and delineate the parameter of concern. The result of this model may provide for a short term estimation purposes [5-8]. 


\section{Study Area}

The length and the catchment area of Terengganu River are $70 \mathrm{~km}$ and $356 \mathrm{~km}^{2}$, respectively. The Terengganu river watershed consist of urban, semi-urban, and natural areas depending in the percent of land use such as forest, commercial, communication, residential, sand mining, urbanization, agriculture, farming and other purposes. Terengganu River is a major river that caused to serious flood each year especially rainfall season starting the early of November and ends in March (Malaysian Meteorological Department, MOSTI). Sampling was undertaken along Terengganu River Basin, which represents from water quality level from downstream, upstream and middle-stream. With the variations of the local monsoon climate, Terengganu River receives variable level of rainfall, which is from 0 to $1750 \mathrm{~mm}$ in dry and wet months respectively and Terengganu state receives huge amount of rain water and the river overspills its bank to create the annual flood event [9]. It is the one of the basins undergoing considerable development and urbanization and is does subjected to pollution from point and non-point sources. From the observation, the situation in Terengganu River Basin indeed in critical and there is a needed for a comprehensive study in order to manipulate the level of the water quality for environmental sustainable management. This study involves 29 main sampling stations that has been determined using DGPS which located around the catchment representing the length of the Terengganu River (upstream to downstream areas) (Table 1 and Figure 1). The research was performed on wet season (January 2016) and dry season (July 2016). The population density is concentrated at the towns of Kuala Terengganu (from Station 1 until Station 6) and Kuala Berang (Station 11). The water samples were collected from 29 sampling station for Dry season and Wet season based on TSS, SSC and DO.
Table 1: Location of Sampling Station at the Terengganu River,

Terengganu, Malaysia

\begin{tabular}{|c|c|c|}
\hline Sampling Stations & Latitude & Longitude \\
\hline Station 1 & $103^{\circ} 8 ' 21.92 " \mathrm{E}$ & $5^{\circ} 20^{\prime} 23.93 " \mathrm{~N}$ \\
\hline Station 2 & $103^{\circ} 6^{\prime} 20.14 " \mathrm{E}$ & $5^{\circ} 19^{\prime} 26.55^{\prime \prime N}$ \\
\hline Station 3 & $103^{\circ} 5^{\prime} 56.80^{\prime \prime} \mathrm{E}$ & $5^{\circ} 19^{\prime} 40.59 " \mathrm{~N}$ \\
\hline Station 4 & $103^{\circ} 5^{\prime} 12.22 " \mathrm{E}$ & $5^{\circ} 18^{\prime} 48.53 " \mathrm{~N}$ \\
\hline Station 5 & $103^{\circ} 5^{\prime} 12.42^{\prime \prime} \mathrm{E}$ & $5^{\circ} 18^{\prime} 32.74 " \mathrm{~N}$ \\
\hline Station 6 & $103^{\circ} 5^{\prime} 50.67 " \mathrm{E}$ & $5^{\circ} 17^{\prime} 7.75 " \mathrm{~N}$ \\
\hline Station 7 & $103^{\circ} 33^{\prime} 3.64 " \mathrm{E}$ & $5^{\circ} 16^{\prime} 14.99^{\prime \prime} \mathrm{N}$ \\
\hline Station 8 & $103^{\circ} 1^{\prime} 32.70^{\prime \prime} \mathrm{E}$ & $5^{\circ} 13^{\prime} 9.00 " \mathrm{~N}$ \\
\hline Station 9 & $103^{\circ} 1^{\prime} 40.09 " \mathrm{E}$ & $5^{\circ} 12^{\prime} 42.04 " \mathrm{~N}$ \\
\hline Station 10 & $103^{\circ} 2^{\prime} 9.46^{\prime \prime} \mathrm{E}$ & $5^{\circ} 737.61 " \mathrm{~N}$ \\
\hline Station 11 & $103^{\circ} 00^{\prime} 31.30^{\prime \prime} \mathrm{E}$ & $5^{\circ} 4^{\prime} 8.14 " \mathrm{~N}$ \\
\hline Station 12 & $102^{\circ} 58^{\prime} 43.16 " \mathrm{E}$ & $5^{\circ} 322.80 " \mathrm{~N}$ \\
\hline Station 13 & $102^{\circ} 57^{\prime} 58.26 " \mathrm{E}$ & $5^{\circ} 4^{\prime} 39.67 " \mathrm{~N}$ \\
\hline Station 14 & $102^{\circ} 56^{\prime} 41.24 " \mathrm{E}$ & $5^{\circ} 4^{\prime} 37.96 " \mathrm{~N}$ \\
\hline Station 15 & $102^{\circ} 56^{\prime} 10.96 " \mathrm{E}$ & $5^{\circ} 3{ }^{\prime} 48.46 " \mathrm{~N}$ \\
\hline Station 16 & $102^{\circ} 55^{\prime} 46.47^{\prime \prime E}$ & $5^{\circ} 2 ' 26.86 " \mathrm{~N}$ \\
\hline Station 17 & $102^{\circ} 55^{\prime} 37.24 " \mathrm{E}$ & $5^{\circ} 1 ' 55.10 " \mathrm{~N}$ \\
\hline Station 18 & $102^{\circ} 56^{\prime} 28.08 " \mathrm{E}$ & $5^{\circ} 3^{\prime} 54.70 " \mathrm{~N}$ \\
\hline Station 19 & $102^{\circ} 57^{\prime} 4.74 " \mathrm{E}$ & $5^{\circ} 4^{\prime} 37.88^{\prime \prime} \mathrm{N}$ \\
\hline Station 20 & $102^{\circ} 58^{\prime} 16.48 " \mathrm{E}$ & $5^{\circ} 3{ }^{\prime} 43.35 " \mathrm{~N}$ \\
\hline Station 21 & $103^{\circ} 0^{\prime} 8.50 " \mathrm{E}$ & $5^{\circ} 4 ' 8.88 " \mathrm{~N}$ \\
\hline Station 22 & $103^{\circ} 0$ 0'25.47"E & $5^{\circ} 4^{\prime} 31.96 " \mathrm{~N}$ \\
\hline Station 23 & $103^{\circ} 2 ' 21.33^{\prime \prime E}$ & $5^{\circ} 8^{\prime} 2.35 " \mathrm{~N}$ \\
\hline Station 24 & $103^{\circ} 2^{\prime} 35.85^{\prime \prime E}$ & $5^{\circ} 11^{\prime} 2.74 " \mathrm{~N}$ \\
\hline Station 25 & $103^{\circ} 1^{\prime} 50.56 " \mathrm{E}$ & $5^{\circ} 12^{\prime} 36.82^{\prime \prime} \mathrm{N}$ \\
\hline Station 26 & $103^{\circ} 2 ' 21.83^{\prime \prime E}$ & $5^{\circ} 13^{\prime} 26.72 " \mathrm{~N}$ \\
\hline Station 27 & $103^{\circ} 4^{\prime} 38.05^{\prime \prime} \mathrm{E}$ & $5^{\circ} 16^{\prime} 37.05^{\prime \prime N}$ \\
\hline $\begin{array}{l}\text { Station } 28 \\
\end{array}$ & $103^{\circ} 5^{\prime 29.09 " \mathrm{E}}$ & $5^{\circ} 17^{\prime} 37.90 " \mathrm{~N}$ \\
\hline Station 29 & $103^{\circ} 5 ' 27.17 " \mathrm{E}$ & $5^{\circ} 18^{\prime} 57.56 " \mathrm{~N}$ \\
\hline
\end{tabular}

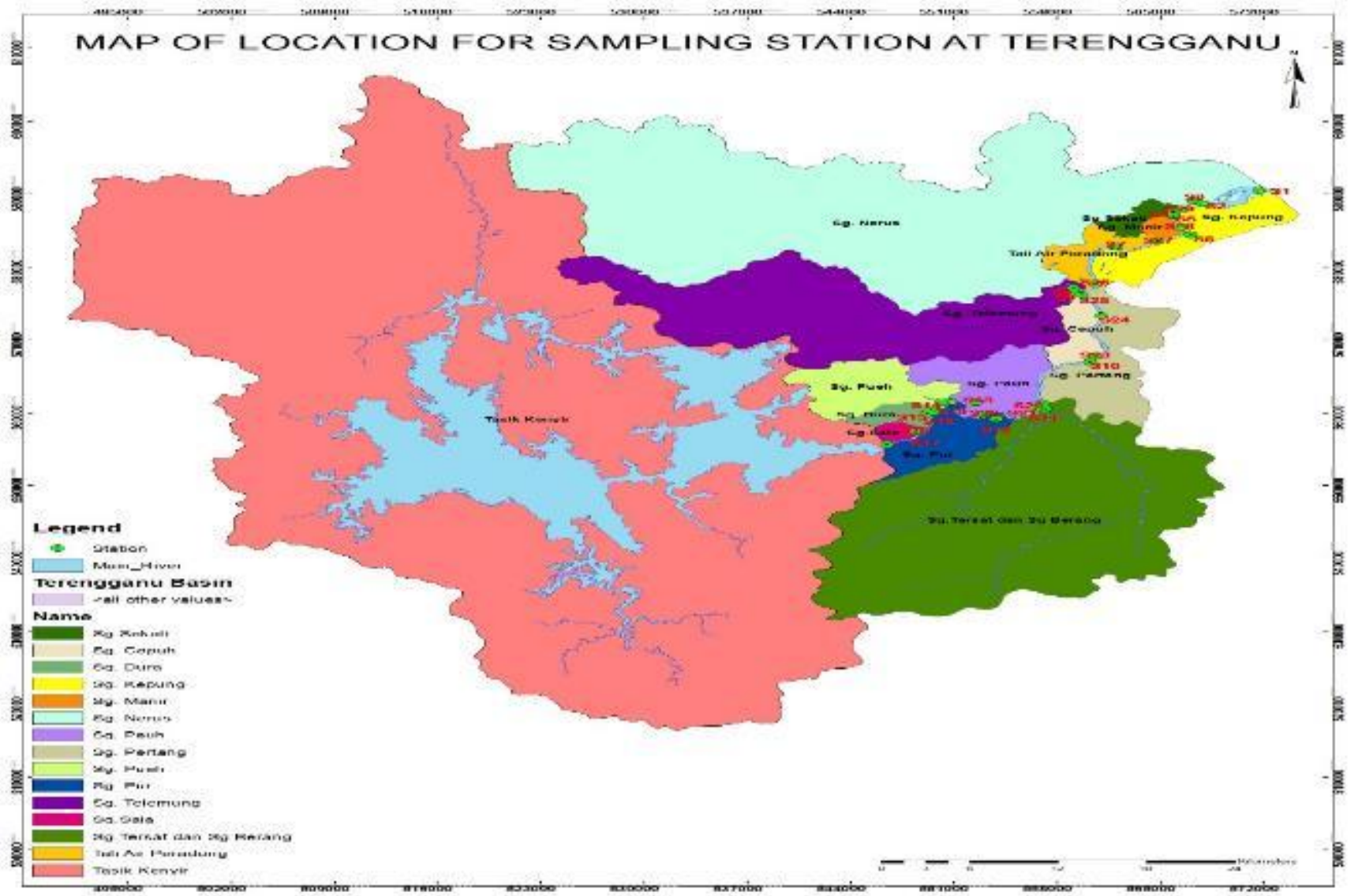

Fig. 1: The Location of Sampling Stations at the Terengganu River, Terengganu, Malaysia 


\section{Methodology}

All the parameters which comprised of DO (mg/l), TSS (mg/l) and SSC (mg/L) were analyzed in accordance to the American Public Health and Association (APHA) standard methods for water and wastewater. The measurements of in situ parameters were DO (mg/L), determined by using the water-quality Multiprobe Model DO meter YSI 58. This multiprobe meter was calibrated before field sampling. TSS and SSC following the procedure outlined by the Gravimetric method $250 \mathrm{ml}$ water sample was needed for each study area was performed by weighing the membrane filter paper $0.45 \mu \mathrm{m}$ (Figure 2). TSS and SSC is measured based on (Equation (1)). Precisely precaution steps should be taken when the river water sample were taken. Interference of the river water flow should be minimum to avoid deposition of the measured suspended sediment $[2,7,10,11]$.

$\mathrm{TSS} / \mathrm{SSC}=\{(\mathrm{WBF}+\mathrm{DR})-\mathrm{WBF}\}(\mathrm{mg}) \times 1000 / \mathrm{VFW}(\mathrm{mL})$ $=\mathrm{mg} / \mathrm{L}$

$* \mathrm{WBF}=$ Weight of membrane filter; $\mathrm{DR}=$ Dry residue; VFW $=$ Volume of filtered water

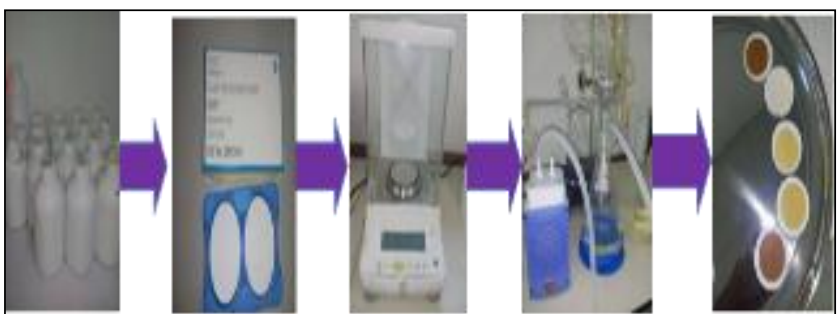

Fig. 2: (a) Water Sample (b) Membrane Filter Paper (c) Electronic Weighing (d) Filtration Apparatus Connected to a Vacuum Pump (e) Dried Membrane Filter

Analysis of variance (ANOVA) is a statistical test for detecting differences in group means when there is one parametric dependent variable and one or more independent variables. This article summarizes the fundamentals of ANOVA for an intended benefit of the clinician reader of scientific literature who does not possess expertise in statistics. The emphasis is on conceptually-based perspectives regarding the use and interpretation of ANOVA, with minimal coverage of the mathematical foundations. Computational examples are provided. Assumptions underlying ANOVA include parametric data measures, normally distributed data, similar group variances, and independence of subjects. Correlation analysis is a method of statistical evaluation used to study the strength of a relationship between two, numerically measured and continuous variables. This particular type of analysis is useful when a researcher wants to establish if there are possible connections between variables. It is often misunderstood that correlation analysis determines cause and effect; however, this is not the case because other variables that are not present in the research may have impacted on the results $[7,11,12]$.

\section{Results and Discussion}

The concentrations of DO in unpolluted waters are usually close to, but less than, $10 \mathrm{mg} / \mathrm{L}$. The minimum and maximum concentration of DO in Terengganu River is $2.11 \mathrm{mg} / \mathrm{L}$ (Station 3) and $8.07 \mathrm{mg} / \mathrm{L}$ (Station 11) respectively during wet season. During dry season recorded the higher DO is $6.05 \mathrm{mg} / \mathrm{L}$ (Station 19) and 2.3 $\mathrm{mg} / \mathrm{L}$ (Station 17). Waste discharges higher in organic matter and nutrients can lead to decreases in DO concentrations as a result of the increased microbial activity (respiration) occurring during the degradation of the organic matter. The measurement of DO can be used to indicate the degree of pollution by organic matter in the river, the destruction of organic substances and the level of selfpurification of the water. The higher concentration of TSS and SSC recorded from middle to downstream stations; Station 1 until Station 9 which are recorded the highest concentration is 67.2 $\mathrm{mg} / \mathrm{L}$ (wet season) and $128.2 \mathrm{mg} / \mathrm{L}$ (dry season) at Station 7, 25.6 $\mathrm{mg} / \mathrm{l}$ (Station 7) during wet season and $24.8 \mathrm{mg} / \mathrm{L}$ (Station 9) during dry season respectively were probably due to discharges of wastes from municipal and development activities. The development construction activities at the river banks near along the downstream and middle stations has probably caused the soils of the river bank to become looser and easily eroded [23]. As a result, the TSS and SSC concentration was higher along downstream and middle-stream areas. Terengganu River is situated downstream of the basin and was expected to show a high TSS and SSC concentration due to its proximity to Kuala Terengganu but a low concentration of TSS was recorded. The sediment solid can be define as the organic and inorganic materials which is moved from one place to another place through the erosion process and deposited in a new location. TSS and SSC used to identify the level of sedimentation problems in the river catchment.

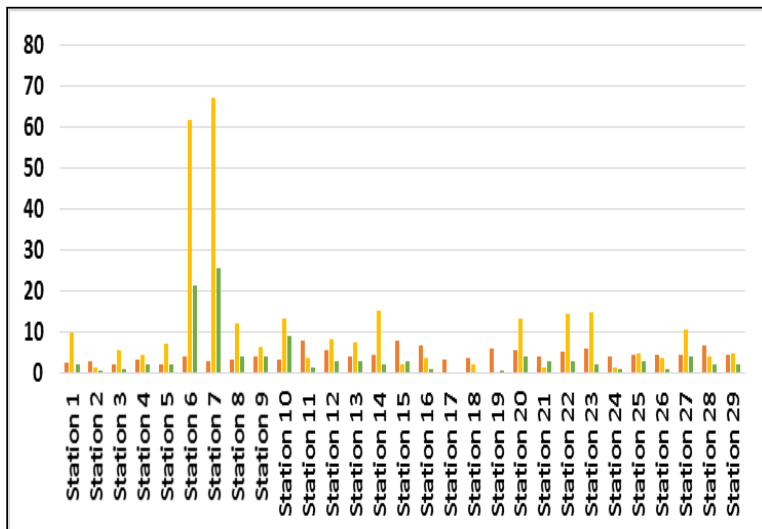

D01 $=$ TSS1 $=S S C$

Fig. 3: The Distribution of DO, TSS and SSC at Terengganu River Basin, Terengganu during Wet Season (January 2016)

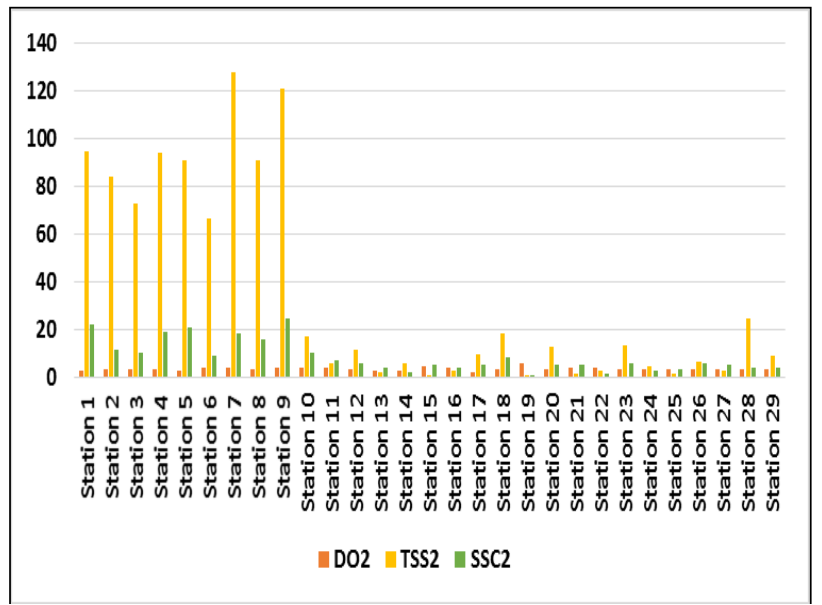

Fig. 4: The Distribution of DO, TSS and SSC at Terengganu River Basin, Terengganu during Dry Season (July 2016)

The three water quality parameter pattern due to 29 station categories are unable to be precisely distinguished, where the discriminate raw data set only recognized three significant $(\mathrm{p}<0.05)$ water quality parameter patterns during wet season $(\mathrm{p}$-value $=$ 0.018007 ) (Table 2 and Table 3 ) and dry season (p-value $=1.18 \mathrm{E}$ 05)) (Table 4 and Table 5). All water quality parameters show significant difference due to spatial variation $(\mathrm{p}<0.05)$. Based on this result, as for the future sampling strategy these water quality 
parameter and sampling station could be used to classify the level of water quality status. All parameters were statistical significant. The box and whisker plot of wet season and dry season (Figure 5) shows that DO, TSS and SSC were statistical significant with $\mathrm{p}<$ 0.005 in 29 stations in Terengganu River Basin. Based on box plot below, the plot trend is random plotted, which are DO, TSS and SSC showed low mean value at 29 stations in Terengganu River. The status of water quality expressed with sub water quality parameters, which concluded that all locations are still under control but the quality of water needs to improve. The main sources of pollution were defined as industries area, poultry, residential areas, recreational park, sewerage and urban areas. Urbanization and agriculture highly significantly influenced the water quality status $[24,25]$. Regarding to this output we found that forested area gave the strong positive value with DO indicates the least pollution. This might be because of strict implementation of pollution control rules and regulations on water quality for industries and other commercial sectors and/or the introduction of some remedial measures taken by the Terengganu River management team and the Department of Environment (DOE) in recent past [13-16].

Table 2: Data Summary for Wet Season of ANOVA Single Factor Results of Terengganu River, Terengganu

\begin{tabular}{|c|c|c|c|c|}
\hline \multicolumn{5}{|c|}{ Summary (Wet Season) } \\
\hline Groups & Count & Sum & Average & Variance \\
\hline DO & 29 & 130.3 & 4.493103 & 2.455951 \\
\hline TSS & 29 & 305 & 10.51724 & 245.69 \\
\hline SSC & 29 & 110.47 & 3.80931 & 33.07056 \\
\hline
\end{tabular}

Table 3: Data Summary for Wet Season of ANOVA Results of the Data at Terengganu River, Terengganu

\begin{tabular}{|c|c|c|c|c|c|c|}
\hline \multicolumn{7}{|c|}{ ANOVA } \\
\hline $\begin{array}{c}\text { Source of } \\
\text { Variation }\end{array}$ & SS & df & MS & F & $\begin{array}{c}\text { P- } \\
\text { value }\end{array}$ & F crit \\
\hline $\begin{array}{c}\text { Between } \\
\text { Groups }\end{array}$ & 790.2901 & 2 & $\begin{array}{c}395.14 \\
51\end{array}$ & $\begin{array}{c}4.2153 \\
82\end{array}$ & $\begin{array}{c}0.0180 \\
07\end{array}$ & $\begin{array}{c}3.1051 \\
57\end{array}$ \\
\hline $\begin{array}{c}\text { Within } \\
\text { Groups }\end{array}$ & 7874.064 & 84 & $\begin{array}{c}93.738 \\
85\end{array}$ & & & \\
\hline Total & 8664.354 & 86 & & & & \\
\hline
\end{tabular}

Table 4: Data Summary for Dry Season of ANOVA Single Factor Results of Terengganu River, Terengganu

\begin{tabular}{|c|c|c|c|c|}
\hline \multicolumn{5}{|c|}{ Summary (Dry Season) } \\
\hline Groups & Count & Sum & Average & Variance \\
\hline TSS & 29 & 996.4 & 34.35862 & 1792.544 \\
\hline SSC & 29 & 244.84 & 8.442759 & 45.72244 \\
\hline DO & 29 & 99.93 & 3.445862 & 0.534725 \\
\hline
\end{tabular}

Table 5: Data Summary for Dry Season of ANOVA Results of the Data at Terengganu River, Terengganu

\begin{tabular}{|c|c|c|c|c|c|c|}
\hline \multicolumn{8}{|c|}{ ANOVA } \\
\hline $\begin{array}{c}\text { Source of } \\
\text { Variation }\end{array}$ & SS & $\begin{array}{c}\text { d } \\
\text { f }\end{array}$ & MS & F & $\begin{array}{c}\text { P- } \\
\text { value }\end{array}$ & F crit \\
\hline Between & 15971. & 2 & 7985.6 & 13.028 & $1.18 \mathrm{E}-$ & 3.1051 \\
Groups & 26 & & 31 & 54 & 05 & 57 \\
\hline Within Groups & 51486. & 8 & 612.93 & & & \\
& 43 & 4 & 37 & & & \\
\hline Total & 67457. & 8 & & & & \\
& 69 & 6 & & & & \\
\end{tabular}

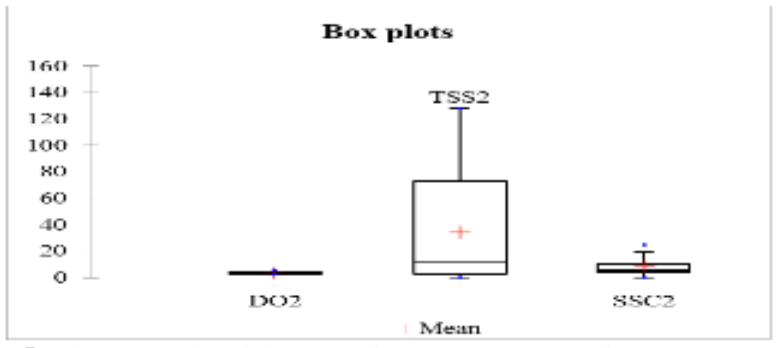

Fig. 5: The Box and Whisker Plot of Three Parameters of Water Quality Parameters during Dry Season (July 2016) in Terengganu River Basin, Terengganu, Malaysia, 2016
If correlation is found between two variables it means that when there is a systematic change in one variable, there is also a systematic change in the other; the variables alter together over a certain period of time. If there is correlation found, depending upon the numerical values measured, this can be either positive or negative. Positive correlation exists if one variable increases simultaneously with the other, i.e. the high numerical values of one variable relate to the high numerical values of the other. Negative correlation exists if one variable decreases when the other increases, i.e. the high numerical values of one variable relate to the low numerical values of the other. From the result, it shows that there is a liner relationship between two variables. We reject hypothesis null and accept hypothesis alternative. We can conclude that, DO $(\mathrm{mg} / \mathrm{l})$ and TSS and SSC shows negative linear relationship with $\mathrm{r}$ $=-0.20565$ and $r=-0.20083$ (wet season).

Based on the result in hypothesis testing for correlation, the researcher accepts ha (hypothesis alternative) because there is have negative relationship between DO (mg/l) and TSS and SSC. There is strength of relationship between TSS and SSC which $r$ is equal to 0.961053 during wet season (Table 6). During dry season (July 2016), TSS and SSC shows negative linear relationship with $r=-$ 0.11694 and $r=-0.1601$ (dry season) Based on the result in hypothesis testing for correlation, the researcher accepts ha (hypothesis alternative) because there is also have negative relationship between DO $(\mathrm{mg} / \mathrm{l})$ and TSS and SSC. There is strength of relationship between TSS and SSC, which $r=0.916995$ during dry season (Table 7) [9, 17-20].

Table 6: Results of Correlation for Wet Season at Terengganu River, Terengganu, 2016

\begin{tabular}{|c|c|c|c|}
\hline & DO & TSS & SSC \\
\hline DO & 1 & & \\
\hline TSS & -0.20565 & 1 & \\
\hline SSC & -0.20083 & 0.961053 & 1 \\
\hline
\end{tabular}

Table 7: Results of Correlation for Dry Season at Terengganu River, Terengganu, 2016

\begin{tabular}{|c|c|c|c|}
\hline & TSS & SSC & DO \\
\hline TSS & 1 & & \\
\hline SSC & 0.916995 & 1 & \\
\hline DO & -0.11694 & -0.1601 & 1 \\
\hline
\end{tabular}

\section{Conclusion}

Water quality status in Terengganu River values were increasing in flow direction of the river (upstream to downstream). Terengganu River Basin is a shallow and small river which has a sensitive ecosystem that responds to the land use changes and activities of its surroundings and climate changes. Water quality analysis showed that SSC and TSS were higher in the both season but Terengganu River is still characterized as good water quality except for some physical characteristics that fluctuate as a result of natural annual season changes. Although the river is used for various water-based activities, it still receives higher water quality status can be considered as good water quality to excellent water quality. The law enforcement is expected to be carried out especially to illegal land use activists around Terengganu River Basin to preserve and conserve this priceless treasure. Terengganu River is a major river in the state that is directly connected to Kenyir Lake in Hulu Terengganu, if without control of the strategic will be disrupt the river ecosystem in the long term and it will give a negative impact on the environment, economics and society. The increasing the suspended solid could lead to increase the turbidity and the odours and colour of water.

\section{Acknowledgement}

The author would like to thank KPM for providing financial support for this research on the SRGS: Pembangunan Pemodelan 
Luahan Persekitaran Ekohidrologi Di Tasik Kenyir, Hulu Terengganu, Terengganu (UniSZA/2017/SRGS/17) - R0019-R017, Department of Irrigation and Drainage Malaysia for the secondary data and East Coast Environmental Research Institute (ESERI), Universiti Sultan Zainal Abidin (UNISZA) give permission to use research facilities and supporting in this research.

\section{References}

[1] Gasim, M B., Toriman, M E H., Abas, A., Islam, M., \& Tan, C C. (2008). Water quality of several feeder rivers between two seasons in Tasik Chini, Pahang. Sains Malaysiana, 37(4), 313-321.

[2] Kamarudin, M K A., Toriman, M E., Syed, A S M., Idris, M H. Jamil, N. R. \& Gasim, M B. (2009). Temporal variability on lowland river sediment properties and yield. American Journal of Environmental Sciences, 5(5), 657-663.

[3] Abdullah, N W. \& Toriman, M E. (2011). Ciri persekitaran hidrologi dan sedimentasi Sungai Telom, Cameron Highlands. ebangi: Jurnal Sains Sosial dan Kemanusiaan, 5(2), 161-172.

[4] Din, H M., Toriman, M E., Mokhtar, M., Elfithri, R, Aziz, N A A., Abdullah, N M., Kamarudin, M K A. (2012). Loading concentrations of pollutant in Alur Ilmu at UKM Bangi campus: Event mean concentration (EMC) approach. Malaysian Journal of Analytical Sciences, 16(3), 353-365.

[5] Zhang, Y., Guo, F., Meng, W., \& Wang, X. (2009). Water quality assessment and source identification of Daliao River Basin using multivariate statistical methods. Environmental Monitoring and Assessment, 152, 105- 121.

[6] Jaafar, O., Toriman, M E H., Idris, M H., Sharifah Mastura, S A. Juahir, H H., Aziz, N A A., Kamarudin, K A., Jamil, N R. (2010). Study of water level-discharge relationship using Artificial Neural Network (ANN) in Sungai Gumum, Tasik Chini Pahang Malaysia. Research Journal of Applied Sciences, 5(1), 20-26.

[7] Wahab, N A., Kamarudin, M K A., Gasim, M B., Umar, R., Ata, F M., \& Sulaiman, N H. (2016). Assessment of total suspended sediment and bed sediment grains in upstream areas of Lata Berangin, Terengganu. International Journal on Advanced Science, Engineering and Information Technology, 6(5), 757-763.

[8] Kamarudin, M K A., Toriman, M E., Wahab, N A., Rosli, H., Ata F M., \& Faudzi, M N M. (2017) Sedimentation study on upstream reach of selected rivers in Pahang River Basin, Malaysia. International Journal on Advanced Science, Engineering and Information Technology, 7(1), 35-41.

[9] Suratman, S., Hang, H C., Shazili, N A M., \& Tahir, N M. (2009). A preliminary study of the distribution of selected trace metals in the Besut River Basin, Terengganu, Malaysia. Bulletin of Environmental Cohehntamination and Toxicology, 82(1), 16-19.

[10] Toriman, M E., Kamarudin, M K A., Aziz, N A A., Din, H M., Ata F M., Abdullah, N M., Abdullah, N W. (2012). Pengurusan sedimen terhadap sumber air bersepadu: satu kajian kes di Sungai Chini, Pekan Pahang. e-Bangi. Jurnal Sains Sosial dan Kemanusiaan, 7(1) 267-283.

[11] Azid, A., Juahir, H., Toriman, M. E., Endut, A., Kamarudin, M. K. A., Rahman, A., \& Nordin, M. (2015). Source apportionment of air pollution: A case study in Malaysia. Jurnal Teknologi, 72(1), 83-88.

[12] Juahir, H., Zain, S M., Yusoff, M K., Hanidza, T T., Armi, A M., Toriman, M E., \& Mokhtar, M. (2011). Spatial water quality assessment of Langat River Basin (Malaysia) using environmetric techniques. Environmental monitoring and assessment, 173(1-4), 625-641.

[13] Shuhaimi O M., Lim E C., \& Mushrifah I. (2007) Water quality changes in Chini Lake, Pahang, West Malaysia. Environmental Monitoring and Assessment, 131(1-3), 279-292.

[14] Rashid, S A A., Gasim, M B., Toriman M E., Juahir H, Kamarudin, .M K A., Azid, A., Aziz, N A A. (2014). Water Quality deterioration of Jinjang River, Kuala Lumpur: Urban risk case water pollution. Arab World Geographer, 16(4), 349-362.

[15] Kamarudin, M K A., Nalado, A M., Kasmuri, A., Toriman, M E., Juahir, H., Umar, R., \& Hassan, A R. (2017). Assessment of river plan changes in Terengganu River using RS and GIS method. Journal of Fundamental and Applied Sciences, 9(2S), 28-45.

[16] Kamarudin, M K A., Idris, M., \& Toriman, M E. (2013). Analysis of Leptobarbus Hoevenii in control environment at natural lakes. American Journal of Agricultural and Biological Science, 8(2), 142-148.
[17] Chang M., Mccullough J D., \& Granillo A B. (1983). Effects of land use and topography on some water quality variables in forested east texas1, 1983.

[18] Kamarudin, M. K. A., Toriman, M. E., Sulaiman, N. H., Ata, F. M., Gasim, M. B., Muhamad, A., Yusoff, W. A., Mokhtar, M., Amran, M. A., Abd Aziz, N. A. (2015). Classification of tropical river using chemometrics technique: Case study in Pahang River, Malaysia. Malaysian Journal of Analytical Sciences, 19(5), 1001-1018.

[19] Adnan, N A., \& Atkinson, P M. (2011). Exploring the impact of climate and land use changes on streamflow trends in a monsoon catchment. International Journal of Climatology, 31(6), 815-831.

[20] Kusin, F M., Muhammad, S N., Zahar, M S M., \& Madzin, Z. (2016). Integrated River Basin Management: incorporating the use of abandoned mining pool and implication on water quality status. Desalination and Water Treatment, 1-11.

[21] Ismail, A., Toriman, M E., Juahir, H., Zain, S M., Habir, N L A., Retnam, A., \& Azid, A. (2016). Spatial assessment and source identification of heavy metals pollution in surface water using several chemometric techniques. Marine pollution bulletin, 106(1), 292 300.

[22] Din, H M., Toriman, M E., Mokhtar, M., Elfithri, R., Aziz, N A A., Abdullah, N M., Kamarudin, M K A. (2012). Loading concentrations of pollutant in Alur Ilmu at UKM Bangi campus: Event mean concentration (EMC) approach. Malaysian Journal of Analytica Sciences, 16(3), 353-365.

[23] Kamarudin, M K A., Toriman, M E., Juahir, H., Azid, A., Gasim, M B., Saudi, A S M., \& Amran, M. A. (2015). Assessment of river plan change using RS and GIS technique. Jurnal Teknologi, 76(1): 31-38.

[24] Azid, A., Juahir, H., Toriman, M E., Kamarudin, M K A., \& Gasim, M B. (2015). Coastal erosion measurement along Tanjung Lumpur to Cherok Paloh, Pahang during the northeast monsoon season. Jurnal Teknologi, 74(1): 27-34.

[25] Kamarudin, M. K. A., Toriman, M. E., Rosli, M. H., Juahir, H., Aziz, N. A. A., Azid, A., ... \& Sulaiman, W. N. A. (2015). Analysis of meander evolution studies on effect from land use and climate change at the upstream reach of the Pahang River, Malaysia. Mitigation and Adaptation Strategies for Global Change, 20(8), 13191334. 